\title{
Malignant Melanoma on the Nasal Planum Treated with Nasal Planectomy in a Cat
}

\author{
鼻鏡に発生した悪性黒色腫に対して鼻鏡切除術を実施した猫の 1 例
}

\author{
Atsuko KOJIMOTO ${ }^{1,2)}$, Teruo ITOH ${ }^{1,2)^{*}}$, Kazuyuki UCHIDA ${ }^{3)}$, James CHAMBERS ${ }^{3)}$ and Hiroki SHII ${ }^{2)}$ \\ 柑本 敦子 1,2) 伊東 輝夫 1,2)* 内田 和幸 3) チェンバーズジェームズ 3) 椎 宏樹 2) \\ 1) Aoba Animal Hospital, 92-1 Aoba-cho, Miyazaki-shi, Miyazaki 880-084, Japan \\ 2)Division of Animal Medical Research, Hassen-kai, 2-27 Onozaki, Saito-shi, Miyazaki 881-0012, Japan \\ ${ }^{3)}$ Department of Veterinary Pathology, Graduate School of Agricultural and Life Sciences, The University of Tokyo, 1-1-1 Yayoi, \\ Bunkyo-ku, Tokyo 113-8657, Japan
}

\begin{abstract}
Summary: Non-ocular melanocytic tumor (NOMT) is rare in cats. NOMTs with high proliferative activity on the nose have been suggested to have a poor prognosis, but there is little information on treatment. We performed a nasal planectomy in a cat with a rapidly growing NOMT on the nasal planum. Histologically, the resected tumor was composed of nongranular epithelioid and spindle cells with moderate nuclear atypia and frequent mitotic figures, and it was diagnosed as a malignant melanoma. The tumor cells were near the caudal margin but were determined to be completely resected. No recurrence or metastasis was observed for more than 5 years after surgery. Nasal planectomy may be a therapeutic option for nasal NOMTs without metastasis in cats.
\end{abstract}

Key words: cat, malignant melanoma, nasal planectomy

要約：眼球以外に発生するメラニン細胞腫瘍（NOMT）は猫では稀な腫瘍である。鼻に発生する増殖活性の高いNOMTは 予後が悪いことが示唆されているが、その治療に関する情報はほとんどない。我々は急速に増大した鼻鏡のNOMTに対し て鼻鏡切除術を実施した。腫瘍は組織学的に顆粒を持たない上皮様ないし紡錘形の細胞から構成され、中等度の異型性と高 い分裂頻度から悪性メラノーマと診断された。腫瘍は尾側の切除縁に近接していたが完全に切除されており、再発や転移は 術後5年間みられなかった。猫の鼻鏡に発生するNOMTでは鼻鏡切除術が治療選択肢のひとつになると思われる。 キーワード：猫、悪性メラノーマ、鼻鏡切除術

Jpn. J. Vet. Anesth. Surg. 51 (1): 8-12, 2020.

Introduction

In cats, non-ocular melanocytic tumors (NOMTs) are rare and have been reported to account for approximately $0.5 \%$ of all skin tumors ${ }^{12)}$. Although histological criteria for malignancy is not yet established for NOMTs, their clinical behaviors often indicate

1) 青葉動物病院（广880-0842 宮崎市青葉町 92-1）

2) 八仙会動物医療研究部（广881-0012宮崎県西都市小野崎 2-27）

3) 東京大学大学院農学生命科学研究科獣医病理（下 113-8657 東京都文京区弥生 1-1-1)

*連絡担当者: 伊東輝夫 E-mail: itohteruo@gmail.com

受付日 2020 年 5 月 1 日 受理日 2020 年 6 月 1 日 malignancy; recurrence and/or metastasis is reportedly observed in $31-67 \%^{3,7,8)}$, and tumor-related death is reported in $\left.54-58 \%{ }^{9}, 11\right)$ of cases. NOMTs with histologically apparent malignant features are classified as malignant melanomas and have a poor prognosis ${ }^{7}$; aggressive surgery is considered the best treatment option.

A recent large-scale study indicates a poor prognosis for NOMTs occurring in the oral cavity or on the lips or nose (nasal planum or mucosa) because of the high histologic grade and the difficulty of wide exci$\operatorname{sion}^{9}{ }^{9}$. However, only a few cases of treatment of nasal NOMTs have been reported with little description 
of the surgical procedure or long-term prognosis ${ }^{7-9}$. Here, we describe a cat with malignant melanoma on the nasal planum treated with nasal planectomy and associated with a favorable long-term prognosis.

\section{Case report}

A 14-year-old spayed female mixed-breed cat presented with a rapidly growing nasal mass that was initially noticed 9 months prior; the cat occasionally licked the mass and often sneezed. The partially ulcerated mass was pink and hairless, measuring $1.8 \times$ $1.8 \mathrm{~cm}$, and was firmly attached to the nasal planum (Fig. 1A) and invading the skin below (Fig. 1B). Physical examination revealed no abnormalities other than the nasal mass, and blood examination revealed the presence of chronic kidney disease (creatinine level of $2.6 \mathrm{mg} / \mathrm{d} l$ ) with no other abnormalities. The mandibular and superficial cervical lymph nodes were not enlarged and thoracic radiography showed no evidence of pulmonary metastasis. Cytology of fine needle aspirate samples from the mass demonstrated abundant spindle or epithelial-like cells with moderate atypia (Fig. 1C). Based on these findings, the mass was diagnosed as a malignant tumor and surgical resection was planned.

Fifteen minutes after the administration of atropine sulfate $(0.05 \mathrm{mg} / \mathrm{kg}, \mathrm{SC})$, fentanyl (Fentanyl injection, Daiichi Sankyo, Tokyo, Japan) at $5 \mu \mathrm{g} / \mathrm{kg}$ was administered as a bolus intravenous injection. Anesthesia was induced with propofol (IV, to effect) and was maintained with isoflurane and oxygen. A constant rate infusion of fentanyl $(5 \mu \mathrm{g} / \mathrm{kg} / \mathrm{h})$ was continued throughout the procedure. After anesthetic induction, $0.25 \mathrm{mg}$ of bupivacaine hydrochloride (Marcain ${ }^{\circledR}$ injection $0.25 \%$, Aspen, Tokyo, Japan) was injected submucosally into the bilateral infraorbital nerves for analgesia.

The cat was placed in sternal recumbency, and the hair around the nasal planum was clipped and aseptically prepped. The nasal planum and upper lip were excised (Fig. 1D) with at least 5-mm margins of normal tissue around the tumor. Hemostasis of the stump was achieved with minimal use of a bipolar electrocautery device. The ventral oral mucosal defects were closed with 3-0 polyglactin 910 (Vicryl, Johnson \& Johnson, North Ryde, Australia) (Fig. $1 \mathrm{E})$ in a simple continuous pattern, and the skin of the muzzle was reconstructed with 4-0 nylon (ELP ${ }^{\circledR}$, Akiyama medical, Tokyo, Japan) in a simple interrupted pattern. The nasal turbinates were excised using a rongeur, and then the nasal mucosa and skin were sutured using 4-0 nylon in a simple interrupted pattern (Fig. 1F).

Post-operatively, analgesia was provided with an infusion of fentanyl $(1 \mu \mathrm{g} / \mathrm{kg} / \mathrm{h})$ for 24 hours. The cat demonstrated normal behavior with a calm expression post-operatively and regained appetite on the fourth day after surgery. Partial dehiscence between the nasal mucosa and skin occurred immediately after suture removal on the 10th day; the site was repaired with 3-0 polyglactin 910 in a simple interrupted pattern. The wound was completely healed at 45 days postoperatively.

Histologically, the resected tumor was composed of nongranular epithelioid and spindle cells (Fig. $1 \mathrm{G})$, which were immunohistochemically positive for S100 (rabbit polyclonal, Dako, Tokyo, Japan) (Fig. $1 \mathrm{H}$ ) and negative for cytokeratin (mouse monoclonal, AE1/AE3, Dako). A high frequency of mitotic figures (10 per 10 high power fields) (Fig. 1I) with cellular atypia led to a diagnosis of malignant melanoma. The tumor cells did not extend to the surgical margins but reached close to the caudal margin. The postoperative course was uneventful, and no tumor recurrence was observed; the cat died of chronic kidney disease 1,921 days after surgical excision of the tumor.

\section{Discussion}

In previous reports of NOMTs in cats, the median or mean age at onset was 11 years, and there was no sex predilection ${ }^{7-9,11)}$. Cats were more likely to develop NOMTs in the tissues of the head ${ }^{3,7,9)}$, but the incidence of nasal NOMTs was rare $(4 \%)^{9)}$. Histologically, non-pigmented NOMTs, like the one in the case described here, comprised $\left.10-42 \%{ }^{3}, 9-11\right)$ of cases, and the mixed epithelial-spindle cell type accounted for $\left.7-33 \%{ }^{9}, 10\right)$ of cases. Histologically, $57 \%(12 / 23)^{9)}$ and $46 \%(36 / 79)^{7)}$ of cases in previous 

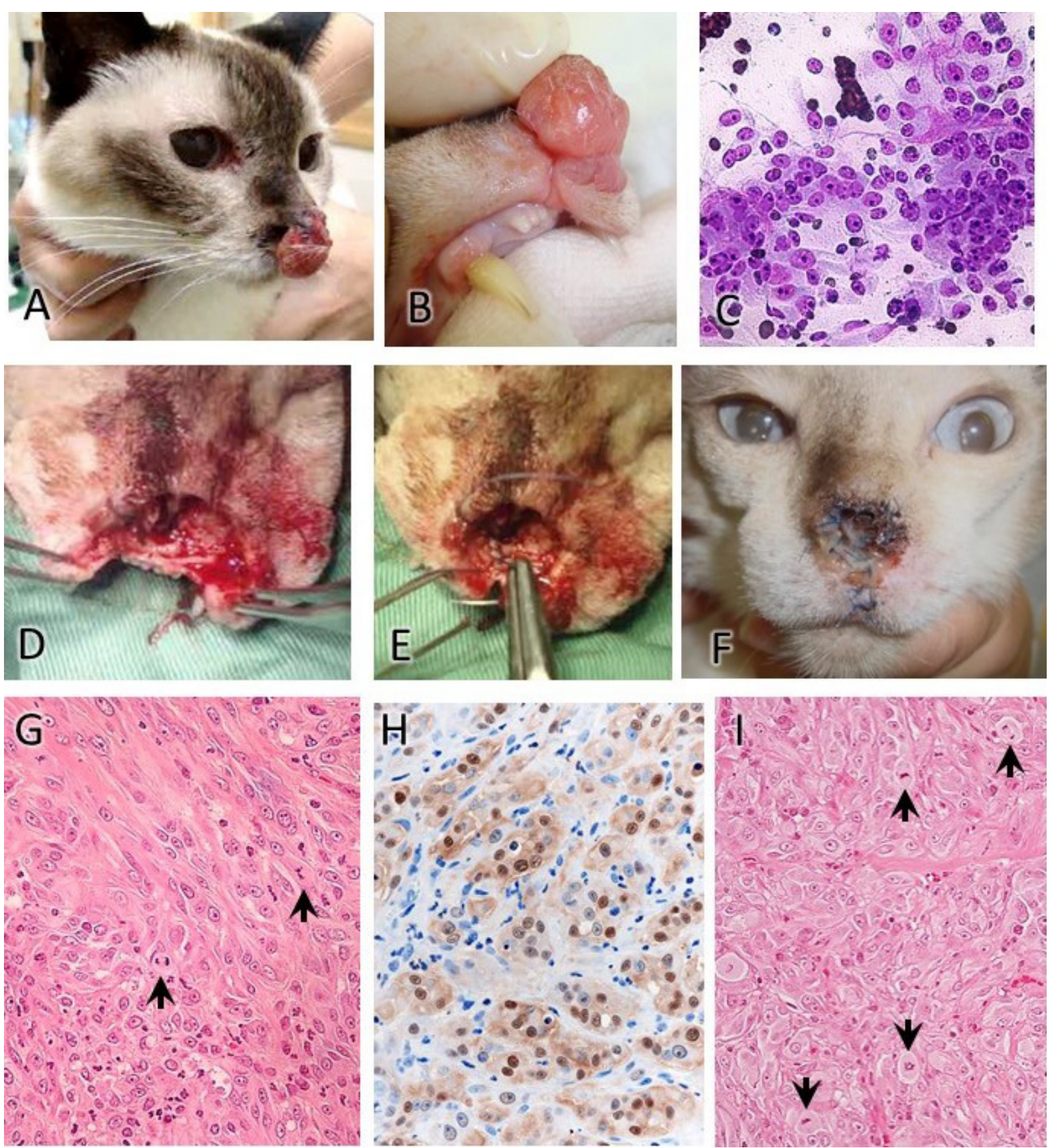

Fig. 1. (A) The gross appearance of malignant melanoma in the nasal planum prior to surgical resection.

(B) The close-up gross appearance of the tumor invasion into the left ventral muzzle prior to surgical resection.

(C) The cytological features of the tumor (Giemsa stain; $\times 400$ ), exhibiting both epithelioid and spindle cells with moderate atypia.

(D) The gross appearance of the nasal planum, ventral muzzle and oral mucosa after surgical excision of the tumor.

(E) The reconstruction of the oral mucosal defect with a simple continuous suture pattern using 3-0 polyglactin.

(F) The gross appearance of the nasal opening prior to suture removal.

(G) The histologic features of the tumor (hematoxylin and eosin stain; $\times 400$ ) demonstrating proliferation of both epithelioid and spindle cells with mitotic figures (arrows).

$(\mathrm{H})$ The tumor cells were immunohistochemically positive for S100 $(\times 400)$.

(I) The histologic features of the tumor (hematoxylin and eosin stain $\times 400$ ); mitotic figures (arrows) were frequently observed at the proliferating sites of epithelioid cells. 
studies were reportedly malignant and high-grade, respectively, although clear criteria for malignancy have not yet been established.

Recent studies have revealed negative prognostic indicators for NOMTs that demonstrate large size $(>1.3 \mathrm{~cm})^{11)}$, poor pigmentation ${ }^{3,9,11)}$, higher proliferative activity ${ }^{9,11)}$, non-epithelial-like cell types $^{11)}$, and nuclear atypia ${ }^{11)}$; most of these criteria were observed in the case described here. Pittaway et al. ${ }^{9)}$ proposed a two-tier grading system including a high probability of tumor-related deaths in highgrade groups ( $80 \%$ sensitivity, $92 \%$ specificity). Nasal NOMTs with $\geq 4$ mitotic index (total number of mitotic images in 10 high-power fields) were considered high-grade cases. Metastases to lymph nodes and other organs, reportedly observed in $31-67 \%$ of NOMT cases $^{3,7,8)}$, may also be a negative prognostic factor; all metastatic cases were euthanized in a previous report ${ }^{8}$. The present case with nasal NOMT was considered high-grade (10 mitotic index); however, early resection of the rapidly growing tumor prior to invasion or metastasis may have contributed to long-term survival.

For non-surgical therapeutic options, the regression of oral melanoma after hypofractionated radiation was observed in three of five cats, but their survival times were short $(66-224 \text { days })^{5}$. A retrospective study on 30 cats with NOMTs revealed shorter median survival in untreated or medically treated cats than in surgically treated cats (71 days vs. 143 days $)^{3)}$. In cats receiving surgery, histologically incomplete resection appeared to be associated with a worse prognosis ${ }^{9,11)}$. Therefore, wide excision is currently considered the best treatment for NOMTs. In the present case, the tumor had histologically reached the cartilage of the nose, indicating that nasal planectomy might be an appropriate procedure. The goal for surgical margins was set as at least 5-mm with reference to the recommendation for squamous cell carcinoma ${ }^{1}$, but its validity for NOMTs warrants further investigation.

Nasal planectomy has been used to treat squamous cell carcinoma in cats ${ }^{1,2,13)}$. A simple procedure in which only the nasal planum is removed and the surrounding skin is sutured with purse-string pattern is often used ${ }^{13)}$, but the upper lip and oral mucosa must be resected if the tumor invades the ventral muzzle ${ }^{2)}$ as in the present case. In such cases, reconstruction of the entire circumference of the nasal stump using the lip and mucosa has been applied in $\operatorname{dog} s^{6}$, although some postsurgical complications including incisional dehiscence $(50 \%)$, oronasal fistula $(23 \%)$, and narrowing of the nasal orifice (19\%) were reported ${ }^{4}$. This method is technically difficult in cats because of a shorter lip length, so we reconstructed the ventral defect by suturing the left and right oral mucosa and lips together. No functional problems or persistent complications were observed postoperatively, and the cosmetic change was accepted by the owner as reported previously ${ }^{13)}$.

The nasal stump and skin were sutured in a single interrupted pattern using non-absorbable sutures, which is considered preferable to the traditional purse-string suture ${ }^{1,2)}$. In our case, wound dehiscence occurred immediately after suture removal on day 10 ; delaying the suture removal or using an absorbable suture that is left in place might be a better method to avoid breakdown of the surgical wound.

The long-term survival of the case described here suggests that NOMTs with highly malignant histological features can be cured if they are completely removed prior to metastasis. Nasal planectomy may be the treatment of choice for malignant melanoma on the nasal planum in cats.

\section{References}

1) Ayres, S. A. and Liptak, J. M. (2012): Nasal planum tumors. In: Veterinary surgical oncology. (Kudnig ST and Seguin B ed), pp. 88-92. Wiley-Blackwell. West Sussex. UK.

2) Chadzimisios, K., Farmaki, R. and Papazoglou, L. G. (2015): Surgical treatment of squamous cell carcinoma of the nasal planum in cats. Hellenic J. Companion Anim. Med. 4: 19-25.

3) Chamel, G., Abadie, J., Albaric, O., Labrut, S., Ponce, F. and Ibisch, C. (2017): Non-ocular melanomas in cats: a retrospective study of 30 cases. J. Feline Med. Surg. 19: 351-357.

4) Dickerson, V. M., Grimes, J. A., Vetter, C. A., Colopy, S. A., Duval, J. M., Northrup, N. C. and Schmiedt, C. W. (2019): Outcome following cosmetic rostral nasal reconstruction after planectomy in 26 dogs. Vet. Surg. 48: 64-69.

5) Farrelly, J., Denman, D. L., Hohenhaus, A. E., Patnaik, A. K. and Bergman, P. J. (2004): Hypofractionated radiation therapy of oral melanoma in five cats. Vet. Radiol. Ultrasound. 45: 9193. 
6) Gallegos, J., Schmiedt, C. W. and McAnulty, J. F. (2007): Cosmetic rostral nasal reconstruction after nasal planum and premaxilla resection: technique and results in two dogs. Vet. Surg. 36: 669-674.

7) Luna, L. D., Higginbotham, M. L., Henry, C. J., Turnquist, S. E., Moore, A. S. and Graham, J. C. (2000): Feline non-ocular melanoma: a retrospective study of 23 cases (1991-1999). J. Feline Med. Surg. 2: 173-181.

8) Patnaik, A. K. and Mooney, S. (1988): Feline melanoma: a comparative study of ocular, oral, and dermal neoplasms. Vet. Pathol. 25: 105-112.

9) Pittaway, R., Dobromylskyj. M. J., Erles, K., Pittaway, C. E., Suárez-Bonnet, A., Chang, Y. M. and Priestnall, S. L. (2019): Nonocular melanocytic neoplasia in cats: characterization and proposal of a histologic classification scheme to more accurately predict clinical outcome. Vet. Pathol. 56: 868-877.
10) Ramos-Vara, J. A., Miller, M. A., Johnson, G. C., Turnquist, S. E., Kreeger, J. M. and Watson, G. L. (2002): Melan A and S100 protein immunohistochemistry in feline melanomas: 48 cases. Vet. Pathol. 39: 127-132.

11) Sabattini, S., Renzi, A., Albanese, F., Fantinati, M., Rigillo, A., Abramo, F., Tornago, R., Tortorella, G., Massaro, M., Pagano, T. B., Buchholz, J. and Bettini, G. (2018): Evaluation of Ki-67 expression in feline non-ocular melanocytic tumours. BMC Vet. Res. 14: 309 .

12) Smith, S. H., Goldschmidt, M. H. and McManus, P. M. (2002): A comparative review of melanocytic neoplasms. Vet. Pathol. 39: 651-678.

13) Withrow, S. J. and Straw, R. C. (1990): Resection of the nasal planum in nine cats and five dogs. J. Am. Anim. Hosp. Assoc 26: $219-223$. 